\title{
Analisis Potensi dan Pengembangan Kerbau Lumpur di Kabupaten Serang
}

\author{
Potential and Development Analysis of Swamp Buffalo in Serang District
}

\author{
Komariah $^{1}$, Burhanuddin $^{2}$, \& N. Permatasari ${ }^{3}$ \\ ${ }^{1}$ Laboratorium Ilmu Produksi Ternak Ruminansia Besar, \\ Fakultas Peternakan, Institut Pertanian Bogor, Jl. Rasamala Kampus IPB Darmaga Bogor 16680 \\ ${ }^{2}$ Laboratorium Bisnis dan Kewirausahaan, Fakultas Ekonomi dan Manajemen IPB \\ Jl. Kamper Kampus IPB Darmaga Bogor 16680 \\ ${ }^{3}$ Laboratorium Ilmu Produksi Ternak Ruminansia Besar, Fakultas Peternakan IPB \\ Email koresponden author: komariah_purjati@yahoo.com
}

\begin{abstract}
Serang District is one of swamp buffalo sentra in Banten Province. The aim of study analyzed Additional Capacity of Ruminant Population (ACRP) and swamp buffalo's productivity in Serang Regency. The number of observation were 64 buffaloes. The result of Additional Capacity of Ruminant Population (ACRP) analysis showed that the population of ruminant livestock in Serang District exceeds the capacity of ruminants based on forage potential of -10 529.68 AU. The cows and bull swamp buffalo productivity hip width was very significant difference $(\mathrm{P}<0.01)$. The swamp buffalo is very potential to be developed in Serang District and has high productivity.
\end{abstract}

Keywords: ACRP, productivity, Serang Regency, swamp buffalo

\section{PENDAHULUAN}

Kebutuhan konsumsi protein hewani terus mengalami peningkatan seiring dengan bertambahnya populasi penduduk Indonesia. Kebutuhan protein hewani dapat terpenuhi salah satunya dari ternak ruminansia besar. Salah satu ternak ruminansia besar yang berpotensi sebagai sumber penghasil daging adalah kerbau. Saat ini pemerintah mencanangkan program grand design swasembada protein hewani untuk menyempurnakan program swasembada daging 2014. Program grand design swasembada protein hewani antara lain adalah grand design sapi potong dan kerbau (Riwantoro 2016).

Peningkatan pertumbuhan penduduk, teknologi dan zaman, menyebabkan ternak kerbau semakin kurang diminati dan menyebabkan lahan hijau semakin sempit. Semua lahan hijau secara perlahan berubah menjadi bangunan bertingkat. Keterbatasan lahan ini menyebabkan lahan untuk peternakan dan ketersediaan hijauan pakan ternak menurun. Ketersediaan pakan secara kontinyu dengan jumlah cukup dan kualitas yang baik sangat diperlukan untuk pertumbuhan ternak. Potensi pengembangan ternak sangat bergantung dengan ketersediaan hijauan di suatu wilayah. Pengembangan populasi ternak kerbau di suatu wilayah dapat diketahui dengan kapasitas peningkatan populasi ternak ruminansia (KPPTR) melalui potensi hijauan yang ada di wilayah tersebut.
Kerbau lumpur adalah salah satu kerbau tipe pekerja dan pedaging yang berpotensi menghasilkan daging. Kerbau memiliki kemampuan untuk hidup di kawasan yang relatif sulit dengan pakan yang berkualitas rendah (Maureen dan Kardiyanto 2010). Penurunan populasi kerbau dan rendahnya konsumsi daging kerbau disebabkan oleh sistem pemeliharaan kerbau berbasis peternakan rakyat. Menurut Gunawan dan Romjali (2009), kerbau memiliki kelemahan dan juga kelebihan.

Kelemahan kerbau yang dikenal masyarakat antara lain tingkat reproduksi rendah, keterbatasan bibit unggul, mutu pakan yang diberikan rendah, sering terjadi perkawinan silang dalam, kurangnya pengetahuan peternak, estrus pada kerbau sulit dideteksi dan masa kebuntingan lebih lama. Kelebihan kerbau yaitu mampu mencerna serat kasar tinggi, dan masa produktivitas panjang. Perbaikan sistem pemeliharaan ternak akan mengoptimalkan produktivitas kerbau. Salah satu indikator yang menentukan produktivitas ternak yaitu bobot badan yang dapat dilihat dari bentuk dan ukuran tubuh.

Provinsi Banten adalah salah satu provinsi yang dijadikan sebagai sentra pengembangan kerbau di Indonesia. Sektor peternakan di Banten ini mempunyai potensi untuk dikembangkan karena dukungan sumberdaya alam yang mencukupi (Maureen dan Kardiyanto 2011). Kabupaten Serang memiliki potensi pengembangan ternak kerbau dengan populasi kerbau tertinggi kedua setelah 
kabupaten Lebak. Jumlah populasi kerbau di Kabupaten Serang sebanyak 28.402 ekor $(29,21 \%)$ dari populasi kerbau di Provinsi Banten (BPS Provinsi Banten 2016). Potensi pengembangan kerbau didukung dengan adanya luasan lahan sumber hijauan yang tersedia yaitu sawah sebanyak 48,925 ha, sawah bera 978,5 ha, tegalan 97,54 ha, perkebunan 359,5 ha, hutan rakyat 335,28 ha dan hutan negara 2,5 ha. Berdasarkan kondisi di atas maka perlu dilakukan penelitian ini.

Penelitian ini bertujuan menganalisis kapasitas peningkatan populasi ternak ruminansia melalui potensi hijauan yang dimiliki oleh wilayah Kabupaten Serang. Selain itu, penelitian ini dilakukan untuk menganalisis produktivitas kerbau lumpur (Swamp buffalo) jantan dan betina pada umur yang berbeda di Kabupaten Serang.

\section{MATERI DAN METODE}

Penelitian ini dilakukan pada bulan April sampai dengan bulan Mei 2017. Penelitian dilakukan di Kecamatan Cinangka dan Mancak Kabupaten Serang, Banten dengan menggunakan kerbau lumpur sebanyak 64 ekor yang terdiri dari 9 ekor jantan berumur 1-3 tahun, 10 ekor betina berumur 1-3 tahun, 20 ekor betina berumur 4-6 tahun, dan 29 ekor betina berumur $>6$ tahun. Data sekunder didapatkan dari Dinas Peternakan Kabupaten Serang, Dinas Pertanian Kabupaten Serang, dan BPS Kabupaten Serang, dan instansi terkait. Alat yang digunakan pada penelitian ini adalah pita ukur, tongkat ukur, kaliper. Alat lain yang juga digunakan kuisioner dan alat tulis.

\section{Analisis Data}

Penelitian ini diawali dengan survey pendahuluan untuk menentukan lokasi penelitian berdasarkan hasil diskusi dengan Dinas Peternakan Kabupaten Serang. Data yang digunakan dalam penelitian ini berupa data primer dan sekunder. Data primer diperoleh dengan wawancara langsung ke peternak serta pengukuran morfometrik tubuh kerbau lumpur (Swamp buffalo). Pemilihan responden/ peternak diambil menggunakan metode convinience sampling berdasarkan kesediaan peternak diwawancara dan dilakukan pengukuran morfometrik tubuh kerbau lumpur untuk mengetahui produktivitas kerbau lumpur (Swamp buffalo).

Data sekunder diperoleh dari Dinas Peternakan Kabupaten Serang, Dinas Pertanian Kabupaten Serang, dan Badan Pusat Statistik Kabupaten Serang, data sekunder tersebut digunakan untuk menghitung Location Quotions (LQ) dan Kapasitas Peningkatan Populasi Ternak Ruminansia (KPPTR). Pengambilan sampel penelitian di Kecamatan Cinangka dan Mancak. Peternak yang diwawancara sebanyak 40 orang. Kerbau lumpur (Swamp buffalo) betina dikelompokan menjadi 3 kelompok yaitu kelompok umur 1-3 tahun, umur 4-6 tahun, dan umur $>6$ tahun. Kerbau lumpur (Swamp buffalo) jantan hanya ada 1 kelompok umur yaitu umur 1-3 tahun.

KPPTR Kabupaten Serang dihitung menggunakan data sekunder berdasarkan potensi hijauan dan limbah pertanian setiap kecamatan dengan nilai konversi yang telah ditentukan pada Tabel 1 dan 2. Nilai LQ merupakan metode yang digunakan untuk menentukan wilayah sentra populasi kerbau lumpur. Analisis LQ disebut dengan keunggulan komparatif untuk mengetahui perbandingan relatif antara kemampuan ternak ruminansia di suatu kecamatan dengan kemampuan sektor yang sama pada tingkat kabupaten. Nilai LQ $>1$ merupakan wilayah yang dapat dikatakan sebagai wilayah pengembangan ternak ruminansia. Rumus menghitung LQ menurut Daryanto dan Hafizriandi (2010):

$$
\mathrm{LQ}=\frac{x i(A) / x(A)}{X i(N) / X(N)}
$$

Keterangan:

LQ : Location quotions

xi (A) : Populasi ternak kerbau ke-i di kecamatan A

$\mathrm{x}$ (A) : Populasi total ternak ruminansia di kecamatan A

Xi(N) : Populasi ternak kerbau ke-i di Kabupaten Serang

$\mathrm{X}(\mathrm{N})$ : Populasi total ternak ruminansia di Kabupaten Serang

\section{Analisis KPPTR}

Potensi ketersediaan hijauan didasarkan pada beberapa sumber yakni: padang rumput, sawah bera, galangan sawah, perkebunan, hutan sejenis, hutan sekunder, tepi jalan dan tegalan (Nell dan Rollinson 1974). Total areal tersebut dianggap dapat menyediakan Bahan Kering sebanyak 3,75/ton/ha/tahun. Berdasarkan data sekunder, total areal dari beberapa sumber potensi hijauan dihitung untuk setiap kecamatan. Angka konversi luas lahan dan jerami yang dapat dimanfaatkan sebagai pakan ternak ditunjukkan pada Tabel 1 dan 2. Total produksi hijauan (ton $\mathrm{BK} /$ tahun) untuk setiap kecamatan dihitung dengan rumus berikut:

$$
\mathrm{TPH}=3,75 \sum \mathrm{LE} \mathrm{i}+\sum \mathrm{PJj}
$$

Keterangan:

TPH : Total produksi hijauan satu kecamatan dalam satu tahun (ton BK tahun-1)

LEi : Luas hijauan efektif (ha) ke-i

PJj : Produksi jerami (ton BK tahun-1) dari sumber ke-j

Kapasitas Tampung Ruminansia (KTR) suatu kecamatan dihitung sebagai berikut:

$$
\mathrm{KTR}(\mathrm{ST})=\frac{T P H(\operatorname{ton} B K / \text { tahun })}{2,3(\operatorname{ton} B K / S T / \text { tahun })}
$$

Keterangan:

KTR(ST): Kapasitas tampung ruminansia dalam satuan ternak

TPH : Total produksi hijauan

2,3 : Kebutuhan BK satu satuan ternak (ST)

Penghitungan jumlah hijauan (ton BK/tahun) yang telah dimanfaatkan dapat dihitung dengan rumus:

$$
\mathrm{KTRU}=2,3 J S T
$$

Keterangan:

KTRU : KTR termanfaatkan

JST : Jumlah populasi ternak ruminansia yang ada (ST) 
Tabel 1. Angka konversi luas lahan penghasil hijauan

\begin{tabular}{ll}
\hline \multicolumn{1}{c}{ Luas riil lahan } & \multicolumn{1}{c}{ Luas lahan tersedia } \\
\hline Luas padang rumput alam & Luas padang rumput alam \\
Luas sawah bera & $20 \%$ dari luas total sawah $\times 10 \%$ \\
Luas galangan sawah & $2,5 \%$ dari luas total sawah \\
Luas perkebunan & $5 \%$ dari luas total perkebunan \\
Luas hutan sejenis/negara & $5 \%$ dari luas total hutan sejenis \\
Luas hutan sekunder/rakyat & $3 \%$ dari luas total hutan sekunder \\
Luas tepi jalan & 0,5 ha $\times$ total panjang jalan \\
Luas tegalan/ladang & $1 \%$ dari luas total tegalan/ladang \\
\hline
\end{tabular}

Sumber: Nell dan Rollinson (1974)

Tabel 2. Angka konversi jerami yang tersedia terhadap pakan ternak

\begin{tabular}{|c|c|}
\hline Luas riil lahan & Luas lahan tersedia \\
\hline Jerami padi & $\begin{array}{l}\text { Luas panen (ha) } \times 0,23 \text { ton } \mathrm{Bhn} \\
\text { Kering/ha/thn }\end{array}$ \\
\hline Jerami Jagung & $\begin{array}{l}\text { Luas panen (ha) } \times 10,9 \text { ton Bhn } \\
\text { Kering/ha/thn }\end{array}$ \\
\hline Jerami ubikayu & $\begin{array}{l}\text { Luas panen (ha) } \times 5,05 \text { ton } \mathrm{Bhn} \\
\text { Kering/ha/thn }\end{array}$ \\
\hline Jerami ubijalar & $\begin{array}{l}\text { Luas panen }(\text { ha) } \times 1,20 \text { ton } \mathrm{Bhn} \\
\text { Kering/ha/thn }\end{array}$ \\
\hline Jerami kedelai & $\begin{array}{l}\text { Luas panen (ha) } \times 1,07 \text { ton Bhn } \\
\text { Kering/ha/thn }\end{array}$ \\
\hline Jerami kacang tanah & $\begin{array}{l}\text { Luas panen (ha) } \times 1,44 \text { ton Bhn } \\
\text { Kering/ha/thn }\end{array}$ \\
\hline
\end{tabular}

Perhitungan KPPTR dilakukan untuk setiap kecamatan, dengan mengkoreksi KTR dengan KTRU, maka diperoleh Kapasitas Penambahan Populasi Ternak Ruminansia (KPPTR), sebagai berikut:

$$
\operatorname{KPPTR}(\mathrm{ST})=\mathrm{KTR}-\mathrm{KTRU}
$$

Keterangan :

KPPTR(ST): Kapasitas penambahan populasi ternak ruminansia (satuan ternak)

KTR : Kapasitas tampung ruminansia

KTRU : KTR termanfaatkan

Pendugaan bobot badan menggunakan rumus Putra (1985) yaitu pendekatan lingkar dada dan panjang badan sebagai berikut:

$$
\log Y=-3,686+1,937 \log X 1+0,902 \log X 2
$$

Keterangan:

$\mathrm{Y} \quad$ : Bobot badan ternak $(\mathrm{kg})$

$\mathrm{X} 1 \quad$ : Lingkar dada $(\mathrm{cm})$

X2 : Panjang badan (cm)

\section{Peubah}

Peubah yang diukur adalah tinggi pinggul, tinggi pundak, dalam dada, panjang badan, lebar pinggul, lebar dada, dan lingkar dada. Morfometrik kerbau lumpur diukur menggunakan tongkat ukur, kaliper, dan pita ukur. Variabel tubuh yang diukur meliputi tinggi pinggul, tinggi pundak, dalam dada, panjang badan, lebar pinggul, lebar dada, lingkar dada berdasarkan Sitorus dan Anggraeni (2009) sebagai berikut:

1. Tinggi pinggul yaitu jarak tertinggi pinggul (Hip bone) dari tulang Tuber coxae tegak lurus ke tanah, diukur menggunakan tongkat ukur.

2. Tinggi pundak yaitu jarak tertinggi pundak (Os vertebra thoracalis) tegak lurus ke tanah diukur menggunakan tongkat ukur.

3. Dalam dada yaitu jarak antara titik tertinggi pundak (Os vertebra thoracalis) dan tulang dada (Os sternum), diukur menggunakan tongkat ukur.

4.Panjang badan yaitu jarak dari tepi tulang Processus spinocus sampai dengan benjolan tulang duduk (Tuber ischii) diukur menggunakan tongkat ukur.

5. Lebar pinggul yaitu jarak antara kedua sendi pinggul dari hip kiri dan hip kanan diukur menggunakan kaliper.

6. Lebar dada yaitu jarak antara penonjolan sendi bahu (Tuber humerus) kiri dan kanan, diukur dengan kaliper.

7. Lingkar dada diukur melingkar tepat di belakang sendi bahu (Os scapula) menggunakan pita ukur.

Rancangan yang digunakan yaitu Rancangan Acak Kelompok (RAK). Data primer yang diperoleh dari pengukuran morfometrik kerbau lumpur dianalisis ragam (ANOVA). Model rancangan percobaan menurut Gaspersz (1991) sebagai berikut:

$$
Y i j=\mu+\tau I+\beta j+\varepsilon i j k
$$

Keterangan:

Yij : pengamatan nilai morfometrik kerbau lumpur ke-i (jantan dan betina) pada umur ke-j (umur 1-3, 4-6, dan $>6$ tahun)

$\mu \quad$ : rataan nilai pengamatan

$\tau \mathrm{i}$ : pengaruh aditif dari perlakuan ke-i (jantan dan betina)

$\beta \mathrm{j}$ : pengaruh aditif dari kelompok umur ke-j (umur 1-3, 4-6, dan $>6$ tahun)

cijk : pengaruh galat percobaan dari perlakuan ke-i (jantan dan betina) pada kelompok umur ke-j (umur 1-3, 4-6, dan $>6$ tahun).

\section{HASIL DAN PEMBAHASAN}

\section{Keadaan Umum Lokasi Penelitian}

Kabupaten Serang sebagai salah satu bagian dari Provinsi Banten berada pada koordinat $105^{\circ} 0^{\prime}-106^{\circ} 22^{\prime}$ BT dan $5^{\circ} 50^{\prime}-6^{\circ} 21^{\prime}$ LS. Wilayah Kabupaten Serang beriklim tropis dengan curah hujan dalam sebulan rata-rata $8 \mathrm{~mm}$ dan lama hujan 12 hari. Suhu berkisar antara $23,4^{\circ} \mathrm{C}-31,8^{\circ} \mathrm{C}$, dan kelembaban relatif sebesar $81 \%$. Sebagian besar dari luas wilayah keseluruhan Kabupaten Serang digunakan untuk lahan di sektor pertanian, hortikultura, perkebunan, dan perikanan.

Secara geografis wilayah Kabupaten Serang sebelah Utara berbatasan dengan Laut Jawa, Kota Cilegon dan Kota Serang. Sebelah Timur berbatasan dengan Kabupaten Tangerang, di sebelah Selatan Kabupaten Lebak dan Kabupaten Pandeglang, sedangkan di sebelah Barat berbatasan dengan Kota Cilegon dan Selat Sunda (BPS Kabupaten Serang). Luas wilayah Kabupaten Serang 
sebesar 146457,941 ha yang terdiri dari 29 kecamatan dan 326 desa. Lahan produksi hijauan di Kabupaten Serang meliputi sawah 60 525,391 ha, galangan sawah 1357,4 ha, tegalan 230,89 ha, perkebunan 4,5 ha, hutan 95,55 ha, panjang tepi jalan 363,77 ha dan lahan penggembalaan 171 ha. Jumlah penduduk Kabupaten Serang pada tahun 2015 adalah 1474.301 jiwa, jumlah penduduk laki-laki 427 134 jiwa dan perempuan 376298 jiwa. Kabupaten Serang didominasi oleh ternak kerbau dengan populasi sebanyak 28 402 ekor dan populasi sapi potong hanya 6447 ekor (BPS Kabupaten Serang 2016).

\section{Karakteristik Peternak Kerbau}

Peternak merupakan salah satu sumberdaya manusia yang memiliki peran penting dalam sektor peternakan. Peternak kerbau lumpur di Kabupaten Serang merupakan peternak rakyat dengan sistem pemeliharaan yang masih sederhana dan kemampuan peternak dalam mengurus ternak sudah cukup baik, tetapi kemampuan peternak dalam menerapkan ilmu baru belum dapat dioptimalkan. Secara umum beberapa karakteristik peternak kerbau lumpur di Kabupaten Serang sebanyak 90\% peternak kerbau lumpur di Kabupaten Serang tergolong usia produktif. Usia yang produktif adalah penduduk yang berusia antara 15-64 tahun (Syamsuddin 2013).

Sebanyak $10 \%$ peternak usia nonproduktif, yaitu peternak berusia lebih dari 64 tahun. Peternak pada usia produktif ini tidak hanya menjadi peternak kerbau, tetapi juga menjadi kuli tani. Hal ini menunjukkan bahwa tenaga kerja di Kecamatan Cinangka, Kabupaten Serang berpotensi dalam pengembangan sektor peternakan dan pertanian. Usia merupakan salah satu faktor yang mempengaruhi kemampuan kerja dan produktifitas seseorang. Batoa et al. (2008), petani yang lebih muda dan sehat memiliki kemampuan fisik yang lebih besar dan lebih tanggap dalam menerima proses adopsi inovasi, petani yang berumur lebih tua memiliki sifat kehati-hatian dan penuh pertimbangan dalam menerima suatu inovasi baru.

Tingkat pendidikan peternak dapat dijadikan salah satu indikator yang menunjukkan peternak tersebut memiliki kemampuan dan keterampilan. Semakin tinggi tingkat pendidikan peternak maka memudahkan peternak menerima inovasi dan cepat menanggapi masalah yang terjadi. Peternak kerbau di Kabupaten Serang sebanyak $85 \%$ hanya mengikuti pendidikan sampai sekolah dasar (SD). Sebanyak 7,5\% sekolah menengah pertama (SMP), $2,5 \%$ sekolah menegah atas (SMA), dan sebanyak $5 \%$ tidak sekolah. Hal ini menunjukkan bahwa pendidikan peternak di Kecamatan Cinangka, Kabupaten Serang masih rendah. Keterampilan dan pengetahuan peternak di Kecamatan Cinangka, Kabupaten Serang dibantu dengan adanya Sentra Peternakan Rakyat pada tahun 2016.

Peternak memiliki pengalaman beternak kerbau yang berbeda-beda. Pengalaman beternak dapat mempengaruhi cara memelihara ternaknya. Peternak yang memiliki banyak pengalaman akan lebih menguasai cara beternak. Peternak umumnya mengetahui cara beternak dari orang tua dan melihat peternak lainnya secara otodidak. Pengalaman beternak kerbau lumpur di Kabupaten Serang sebanyak
50\% dari 1-10 tahun, karena kebanyakan peternak tidak secara terus-menerus beternak kerbau selama hidupnya.

Sebanyak $12,5 \%$ peternak kerbau lumpur di Kabupaten Serang menjadikan beternak kerbau sebagai usaha utama, 87,5\% sebagai usaha sampingan dengan usaha utamanya sebagai kuli tani. Skala kepemilikan ternak kerbau 55\% yaitu 3-4 ekor, 30\% skala kepemilikan 1-2 ekor, $10 \%$ skala kepemilikan 5-7 ekor. Perbedaan skala kepemilikan ternak kerbau lumpur ini didasari oleh kemampuan peternak dalam kesanggupan peternak memelihara kerbau. Peternak memikirkan kemampuan peternak tersebut dalam penyediaan pakan dan waktu untuk mengangon kerbau.

Kepemilikan ternak kerbau juga dipengaruhi oleh tujuan dari peternak itu sendiri. Sebanyak $87,5 \%$ beternak kerbau sebagai tabungan, $1,5 \%$ sebagai sumber penghasilan utama. Peternak yang menjadikan beternak kerbau sebagai tabungan, memiliki sumber penghasilan utama dari bertani. Peternak dengan usia diatas $>60$ tahun menjadikan beternak kerbau sebagai sumber penghasilan utama, karena pada usia tersebut sudah tidak kuat untuk bekerja yang lain. Peternak usia $<20$ tahun beternak kerbau sebagai sumber penghasilan utama, karena tidak memiliki pekerjaan lain dan sudah tidak melanjutkan pendidikan selanjutnya.

\section{Kapasitas Peningkatan Populasi Ternak Ruminansia (KPPTR)}

Ketersediaan hijauan pakan ternak merupakan salah satu faktor penentu dalam pengembangan ternak ruminansia. Hijauan pakan ternak tiap wilayah memiliki potensi yang berbeda-beda. Potensi hijauan tersebut dapat digunakan untuk mengoptimalkan pemanfaatan sumberdaya alam dalam menunjang peningkatan produksi ternak suatu di daerah. LQ (Location Quotions) digunakan untuk mengetahui wilayah basis pengembangan ternak kerbau lumpur di Kabupaten Serang. Nilai (Location Quotions) LQ dihitung berdasarkan jumlah populasi ternak kerbau lumpur maupun ternak ruminansia yang ada di Kabupaten Serang.

Basis ternak kerbau lumpur di Kabupaten Serang dapat diketahui melalui nilai LQ (Location Quotions) pada tiap kecamatan di Kabupaten Serang. Nilai Location Quotions (LQ) dan Kapasitas Peningkatan Populasi Ternak Ruminansia (KPPTR) tiap kecamatan disajikan pada Tabel 3. Jika nilai $L Q>1$ maka wilayah tersebut merupakan basis kerbau sehingga wilayah tersebut dapat digunakan sebagai wilayah pengembangan ternak kerbau lumpur. Semakin tinggi nilai LQ maka semakin tinggi juga kinerja pada subsektor tersebut, sehingga nilai LQ menggambarkan keunggulan kompetitif suatu subsektor di suatu wilayah. Berdasarkan perhitungan nilai LQ di atas menunjukan bahwa 55,17\% kecamatan di Kabupaten Serang memiliki nilai $L Q>1$ dan dapat digunakan sebagai wilayah basis pengembangan kerbau lumpur, sedangkan 44,83\% kecamatan di Kabupaten Serang memiliki nilai $\mathrm{LQ}<1$, sehingga bukan merupakan wilayah basis pengembangan ternak kerbau lumpur.

Berdasarkan analisis pada Tabel 3, nilai KPPTR Kabupaten Serang negatif yaitu -109 827,40 ST dan luasan lahan hijauan sebesar 3966,01 ha. Hal ini menunjukan bahwa populasi ternak ruminansia di Kabupaten Serang 
Komariah et al.

Jurnal Ilmu Produksi dan Teknologi Hasil Peternakan 6 (3): 90-97

Tabel 3. Kapasitas peningkatan populasi ternak ruminansia di Kabupaten Serang

\begin{tabular}{|c|c|c|c|c|c|c|}
\hline Kecamatan & TPH (ton BK tahun-1) & $\begin{array}{l}\text { KTR } \\
\text { (ST) }\end{array}$ & $\begin{array}{l}\text { JST } \\
\text { (ST) }\end{array}$ & KTRU (ST) & KPPTR (ST) & Luasan Lahan (Ha) \\
\hline Cinangka & 5306,31 & 2307,09 & 1093,79 & 2515,71 & $-208,62$ & 172,45 \\
\hline Padarincang & 2750,69 & 1195,95 & 1205,52 & 2772,70 & $-1576,75$ & 220,95 \\
\hline Ciomas & 2191,62 & 952,88 & 846,74 & 1947,51 & $-994,63$ & 81,34 \\
\hline Pabuaran & 1555,62 & 676,36 & 7412,91 & 17049,70 & $-16373,34$ & 102,02 \\
\hline Gunung Sari & 1893,05 & 823,07 & 1151,00 & 2647,29 & $-1824,23$ & 423,82 \\
\hline Baros & 1816,47 & 789,77 & 638,53 & 1468,63 & $-678,85$ & 92,94 \\
\hline Petir & 3673,30 & 1597,09 & 1555,96 & 3578,71 & $-1981,62$ & 90,26 \\
\hline T. Teja & 4096,48 & 1781,08 & 1071,74 & 2465,00 & $-683,92$ & 201,04 \\
\hline Cikeusal & 2320,65 & $1.008,98$ & 5444,95 & 12523,39 & $-11514,41$ & 140,29 \\
\hline Pamarayan & 4001,16 & 1739,64 & 1428,66 & 3285,91 & $-1546,27$ & 118,34 \\
\hline Bandung & 1972,31 & 857,53 & 438,48 & 1008,51 & $-150,98$ & 108,79 \\
\hline Jawilan & 1580,04 & 686,97 & 685,70 & 1577,12 & $-890,14$ & 83,37 \\
\hline Kopo & 3701,23 & 1609,23 & 1785,79 & 4107,32 & $-2498,09$ & 321,78 \\
\hline Cikande & 1517,90 & 659,96 & 4614,90 & 10614,27 & $-9954,31$ & 103,95 \\
\hline Kibin & 1816,74 & 789,89 & 695,36 & 1599,34 & $-809,45$ & 61,08 \\
\hline Kragilan & 872,00 & 379,13 & 2207,54 & 5077,34 & $-4698,21$ & 69,99 \\
\hline W. Kurung & 1183,43 & 514,53 & 2186,59 & 5029,16 & $-4514,63$ & 150,62 \\
\hline Mancak & 2229,08 & 969,16 & 3204,97 & 7371,42 & $-6402,26$ & 217,51 \\
\hline Anyar & 1662,86 & 722,98 & 3553,50 & 8173,05 & $-7450,07$ & 82,72 \\
\hline Bojonegara & 4386,12 & 1907,01 & 2328,08 & 5354,58 & $-3447,57$ & 52,71 \\
\hline Pulo Ampel & 660,74 & 287,28 & 1897,40 & 4364,03 & $-4076,75$ & 27,70 \\
\hline Kr. Watu & 1720,13 & 747,88 & 472,01 & 1085,63 & $-337,74$ & 131,17 \\
\hline Ciruas & 1521,05 & 661,33 & 1211,04 & 2785,38 & $-2124,06$ & 131,08 \\
\hline Pontang & 1920,07 & 834,81 & 1021,90 & 2350,38 & $-1515,56$ & 150,96 \\
\hline L. Wangi & 2177,50 & 946,74 & 1356,45 & 3119,83 & $-2173,09$ & 133,04 \\
\hline Carenang & 844,33 & 367,10 & 3075,43 & 7073,48 & $-6706,38$ & 106,84 \\
\hline Binuang & 1180,15 & 513,11 & 1164,74 & 2678,89 & $-2165,79$ & 98,94 \\
\hline Tirtayasa & 921,73 & 400,75 & 2665,00 & 6129,49 & $-5728,74$ & 176,49 \\
\hline Tanara & 1390,08 & 604,38 & 3219,69 & 7405,80 & $-6800,92$ & 113,82 \\
\hline Total & 62862,85 & 27331,67 & 59634,38 & 137159,07 & $-109827,40$ & 3966,01 \\
\hline
\end{tabular}

Keterangan: TPH: Total Produksi Hijauan; KTR: Kapasitas Tampung Ruminansia; JST: Jumlah Ternak Ruminansia (Satuan Ternak); KTRU: Hijauan yang termanfaatkan; KPPTR: Kapasitas Peningkatan Populasi Ternak Ruminansia; ST: Satuan Ternak; BK: Bahan Kering.

sudah melebihi kapasitas tampung ternak, sehingga harus ada sejumlah ternak keluar dari wilayah tersebut agar terjadi keseimbangan antara populasi ternak ruminansia dengan potensi hijauan. Sejumlah ternak ruminansia dapat dikeluarkan dari Kabupaten Serang melalui peningkatan pemotongan ternak tidak produktif, penyaluran daging, dan penjualan ternak hidup ke wilayah lain selain Kabupaten Serang. Nilai KPPTR yang negatif juga diduga oleh adanya perusahaan feedlot sapi seperti PT Lembu Jantan Perkasa di Kecamatan Pabuaran dan Nissin Sinto di Kabupaten Serang. Perusahaan feedlot memiliki pakan sendiri yang data pakannya tidak ada di BPS Kabupaten Serang.

Nilai KPPTR Kabupaten Serang, pada Kecamatan Pabuaran, Cikeusal, dan Cikande terlihat nilai negatif tertinggi yaitu -16 373,34, -11 514,41, dan -9 954,31. Hal ini dapat disebabkan oleh rendahnya produksi hijauan dibandingkan dengan populasi ternak ruminansia yang ada sehingga kapasitas tampung ternak sedikit dibandingkan kapasitas tampung ternak ruminansia yang dimanfaatkan. Potensi hijauan pakan di wilayah tersebut tidak mencukupi untuk memenuhi kebutuhan ternak ruminansia. Dalam rangka pemenuhan pakan ternak, sepertinya 3 kecamatan tersebut mengambil pakan dari luar wilayahnya. Kecamatan dengan nilai KPPTR negatif masih dapat dikembangkan melalui usaha lain seperti penggemukan ternak ruminansia sehingga daerah tetap dapat digunakan sebagai sentra produksi ternak ruminansia terutama pengembangan lahan hijauan pakan ternak serta memanfaatkan lahan-lahan kosong sebagai tanaman sumber hijauan. 
Berdasarkan analisis pada Tabel 3, nilai KPPTR Kabupaten Serang negatif yaitu -10 529,68 ST dengan luasan lahan hijauan sebesar 3966,01 ha. Hal ini menunjukan bahwa populasi ternak ruminansia di Kabupaten Serang sudah melebihi kapasitas tampung ternak, sehingga harus ada sejumlah ternak keluar dari wilayah tersebut agar terjadi keseimbangan antara populasi ternak ruminansia dengan potensi hijauan. Berdasarkan nilai KPPTR Kabupaten Serang, terdapat 10 kecamatan atau sebesar $34,48 \%$ dari total 29 kecamatan yang menunjukan angka positif namun secara keseluruhan Kabupaten Serang sudah tidak memungkinkan untuk dilakukan pengembangan ternak ruminansia kerbau lumpur. Akan tetapi nilai KPPTR positif pada 10 kecamatan tersebut dapat dijadikan sebagai salah satu solusi untuk peningkatan pengembangan ternak ruminansia khususnya kerbau lumpur di Kabupaten Serang.

Nilai KPPTR Kabupaten Serang, pada Kecamatan Cikeusal, Cikande, dan Anyar terlihat nilai negatif tertinggi yaitu -3 585,48, -2 218,17, -2 160,25. Dilihat dari nilai tersebut, sebenarnya tiga kecamatan tersebut sudah melebihi kapasitas tampung ternak ruminansia. Hal ini dapat disebabkan oleh rendahnya produksi hijauan dibandingkan dengan populasi ternak ruminansia yang ada sehingga kapasitas tampung ternak sedikit dibandingkan kapasitas tampung ternak ruminansia yang dimanfaatkan. Potensi hijauan pakan di wilayah tersebut tidak mencukupi untuk memenuhi kebutuhan ternak ruminansia. Dalam rangka pemenuhan pakan ternak, sepertinya tiga kecamatan tersebut mengambil pakan dari luar wilayahnya masingmasing. Kecamatan dengan nilai KPPTR negatif masih dapat dikembangkan melalui usaha lain seperti penggemukan ternak ruminansia sehingga daerah tetap dapat digunakan sebagai sentra produksi ternak ruminansia terutama pengembangan lahan hijauan pakan ternak serta memanfaatkan lahan-lahan kosong sebagai tanaman sumber hijauan.

\section{Produktivitas Kerbau Lumpur}

Pengukuran morfometrik kerbau lumpur di Kabupaten Serang meliputi pengukuran tinggi pinggul, tinggi pundak, dalam dada, panjang badan, lebar pinggul, lebar dada, lingkar dada, dan bobot badan. Pengukuran morfometrik dilakukan untuk mengetahui produktivitas kerbau lumpur dalam usaha pengembangan kerbau lumpur di Kabupaten Serang. Hasil perhitungan morfometrik kerbau lumpur di Kabupaten Serang disajikan pada Tabel 4.

Pengembangan kerbau dapat dilakukan dengan seleksi bibit unggul, antara lain dengan cara pengukuran morfometrik. Populasi ternak kerbau dapat ditingkatkan bila ketersediaan hijauan pakan yang berkualitas baik terjamin, oleh karena itu pakan merupakan faktor utama yang mempengaruhi produktivitas ternak, selain potensi genetik dan lingkungan (Utomo dan Prawirodigdo 2009). Produktivitas ternak kerbau dapat dianalisis melalui bobot badan, sementara bobot badan dapat diduga dengan pengamatan frame size dan ukuran morfometrik. Komariah et al. (2015), morfometrik adalah studi yang berkaitan dengan perubahan bentuk, ukuran ternak yang didasarkan pada data pengukuran tubuh ternak yang mewakili variasi bentuk dan ukuran.

Bobot badan merupakan salah satu parameter penting dalam menilai kualitas ternak. Bobot badan dapat dijadikan indikator tingkat pertumbuhan dan ukuran morfometrik tubuh dapat memberi informasi pada konformasi tubuh yang mencerminkan perkembangan kerangka tubuh (Anggraeni dan Triwulanningsih 2008). Bobot badan dan pertumbuhan ternak dapat diketahui dan ditaksir melalui pengukuran morfometrik (Komariah et al. 2015). Pencapaian bobot badan yang baik pada umur lebih muda dipengaruhi oleh performa morfometrik yang baik, sehingga kerbau dapat dikawinkan pada umur muda (Komariah et al. 2015).

Hasil pengukuran morfometrik tubuh pada kerbau lumpur betina sudah di atas literatur. Hasil pengukuran pada lebar pinggul, lebar dada, dan lingkar dada kerbau lumpur jantan di bawah literatur. Hasil pengukuran pada tinggi pinggul, tinggi pundak, dalam dada, panjang badan, dan bobot badan kerbau lumpur jantan sudah di atas literatur. Berdasarkan hasil perhitungan nilai morfometrik tubuh kerbau lumpur jantan dan betina pada Tabel 4 menunjukan bahwa ukuran dan bentuk tubuh kerbau betina sedikit lebih besar dari kerbau jantan, tetapi tidak ada perbedaan yang nyata pada ukuran tinggi pinggul, tinggi pundak, dalam dada, panjang badan, lebar dada, lingkar dada, dan bobot badan. Hal ini menunjukan bahwa jenis kelamin kerbau tidak berpengaruh nyata pada sebagian besar parameter

Tabel 4. Morfometrik kerbau lumpur jantan dan betina dengan umur yang berbeda

\begin{tabular}{lcccc}
\hline Parameter tubuh & \multicolumn{2}{c}{ Rataan \pm SD } & Literatur \\
\cline { 2 - 5 } & Jantan & Betina & $108 \mathrm{~cm}^{1)}$ & Betina \\
\hline Tinggi pinggul & $115,39 \pm 4,51$ & $119,25 \pm 3,36$ & $110 \mathrm{~cm}^{1)}$ & $113 \mathrm{~cm}^{1)}$ \\
Tinggi pundak & $115,50 \pm 4,41$ & $121,78 \pm 4,23$ & $64,25 \pm 2,87^{2)}$ & $115 \mathrm{~cm}^{1)}$ \\
Dalam dada & $63,06 \pm 5,17$ & $69,55 \pm 4,71$ & $110 \mathrm{~cm}^{1)}$ & $65,64 \pm 9,22^{3)}$ \\
Panjang badan & $118,28 \pm 7,54$ & $132,52 \pm 9,21$ & $44,00 \pm 1,41$ & $120 \mathrm{~cm}^{1)}$ \\
Lebar pinggul & $39,11 \pm 3,14 \mathrm{~b}$ & $47,61 \pm 5,10 \mathrm{a}$ & $39,50 \pm 1,29^{2)}$ & $38,32 \pm 4,58 \pm 6,79^{3)}$ \\
Lebar dada & $32,11 \pm 2,03$ & $36,31 \pm 3,88$ & $180 \mathrm{~cm}^{1)}$ & $170 \mathrm{~cm}^{1)}$ \\
Lingkar dada & $164,41 \pm 8,79$ & $177,71 \pm 12,59$ & $300 \mathrm{~kg}^{1)}$ & $250 \mathrm{~kg}^{1)}$ \\
Bobot badan & $300,3 \pm 39,90$ & $388,49 \pm 67,05$ & \\
\hline Ken
\end{tabular}

Keterangan: Angka yang disertai huruf kecil berbeda pada baris yang sama menunjukan berbeda sangat nyata (P<0,01); Sumber: 1) SNI 7706. 1: 2011; 2) Gerli et al. (2012); 3) Komariah et al. (2015) 
yang diukur pada 3 kelompok umur berbeda. Perbedaan sangat nyata terdapat pada parameter lebar pinggul kerbau lumpur $(\mathrm{P}<0,01)$.

Jenis kelamin kerbau berpengaruh sangat nyata terhadap lebar pinggul kerbau lumpur $(\mathrm{P}<0,01)$. Lebar pinggul pada kerbau betina memiliki nilai lebih besar dibandingkan dengan lebar pinggul pada kerbau jantan. Kerbau betina mengalami pertumbuhan organ reproduksi di dalam pinggul sehingga sudah jelas bahwa kerbau lumpur betina memiliki lebar pinggul yang sangat berbeda nyata dengan kerbau lumpur jantan karena kerbau lumpur betina melahirkan anak. Semakin bertambahnya umur, maka lebar pinggul akan meningkat juga, tetapi pertumbuhan lebar pinggul ini akan berhenti sesudah mencapai dewasa tubuh (Nurfaridah 2009).

Berdasarkan perhitungan nilai kapasitas peningkatan populasi ternak ruminansia (KPPTR) dan produktivitas kerbau lumpur melalui pengukuran morfometrik tubuh dapat diduga bahwa ada penambahan pakan seperti leguminosa, rumput lokal, dan hijauan lain yang tidak diperhitungkan. Kerbau diduga memiliki kemampuan baik dalam beradaptasi dan menyerap pakan berkualitas rendah. Kondisi kualitas pakan yang buruk menyebabkan kerbau lebih efisien dalam memanfaatkan pakan dibandingkan sapi (Handiwirawan et al. 2008).

Kerbau lumpur di Kabupaten Serang ini hampir sepanjang hari diberi kesempatan berendam di sungai dan lumpur sehingga produktivitas kerbau lumpur cukup baik. Kerbau tidak tahan terhadap panas karena kelenjar keringat dan bulu yang dimiliki sedikit sehingga akan menderita bila langsung terkena sinar matahari dalam waktu lama dan stres panas ini membuat laju pertumbuhan dan produktivitas menurun (Handiwirawan et al. 2008). Kelebihan daya tampung ternak juga dipengaruhi oleh penggunaan kerbau lumpur sebagai ternak pekerja membajak sawah.

\section{KESIMPULAN}

Kabupaten Serang berpotensi sebagai wilayah pengembangan kerbau dengan meningkatkan daya dukung lahan sumber hijauan. Produktivitas kerbau lumpur di Kabupaten Serang cukup tinggi.

\section{DAFTAR PUSTAKA}

BPS (Badan Pusat Statistik Provinsi Banten). 2016. Banten dalam Angka 2016. Banten (ID): BPS Provinsi Banten.

BPS (Badan Pusat Statistik Kabupaten Serang). 2016. Kecamatan Anyar dalam Angka 2016. Serang (ID): BPS Kabupaten Serang.

BPS (Badan Pusat Statistik Kabupaten Serang). 2016. Kecamatan Bandung dalam Angka 2016. Serang (ID): BPS Kabupaten Serang.

BPS (Badan Pusat Statistik Kabupaten Serang). 2016. Kecamatan Baros dalam Angka 2016. Serang (ID): BPS Kabupaten Serang.

BPS (Badan Pusat Statistik Kabupaten Serang). 2016. Kecamatan Binuang dalam Angka 2016. Serang (ID):
BPS Kabupaten Serang.

BPS (Badan Pusat Statistik Kabupaten Serang). 2016. Kecamatan Carenang dalam Angka 2016. Serang (ID): BPS Kabupaten Serang.

BPS (Badan Pusat Statistik Kabupaten Serang). 2016. Kecamatan Cikande dalam Angka 2016. Serang (ID): BPS Kabupaten Serang.

BPS (Badan Pusat Statistik Kabupaten Serang). 2016. Kecamatan Cinangka dalam Angka 2016. Serang (ID): BPS Kabupaten Serang.

BPS (Badan Pusat Statistik Kabupaten Serang). 2016. Kecamatan Ciomas dalam Angka 2016. Serang (ID): BPS Kabupaten Serang.

BPS (Badan Pusat Statistik Kabupaten Serang). 2016. Kecamatan Ciruas dalam Angka 2016. Serang (ID): BPS Kabupaten Serang.

BPS (Badan Pusat Statistik Kabupaten Serang). 2016. Kecamatan Gunung Sari dalam Angka 2016. Serang (ID): BPS Kabupaten Serang.

BPS (Badan Pusat Statistik Kabupaten Serang). 2016. Kecamatan Jawilan dalam Angka 2016. Serang (ID): BPS Kabupaten Serang.

BPS (Badan Pusat Statistik Kabupaten Serang). 2016. Kecamatan Kibin dalam Angka 2016. Serang (ID): BPS Kabupaten Serang.

BPS (Badan Pusat Statistik Kabupaten Serang). 2016. Kecamatan Kramat Watu dalam Angka 2016. Serang (ID): BPS Kabupaten Serang.

BPS (Badan Pusat Statistik Kabupaten Serang). 2016. Kecamatan Kopo dalam Angka 2016. Serang (ID): BPS Kabupaten Serang.

BPS (Badan Pusat Statistik Kabupaten Serang). 2016. Kecamatan Mancak dalam Angka 2016. Serang (ID): BPS Kabupaten Serang.

BPS (Badan Pusat Statistik Kabupaten Serang). 2016. Kecamatan Pabuaran dalam Angka 2016. Serang (ID): BPS Kabupaten Serang.

BPS (Badan Pusat Statistik Kabupaten Serang). 2016. Kecamatan Padarincang dalam Angka 2016. Serang (ID): BPS Kabupaten Serang.

BPS (Badan Pusat Statistik Kabupaten Serang). 2016. Kecamatan Pamarayan dalam Angka 2016. Serang (ID): BPS Kabupaten Serang.

BPS (Badan Pusat Statistik Kabupaten Serang). 2016. Kecamatan Petir dalam Angka 2016. Serang (ID): BPS Kabupaten Serang.

BPS (Badan Pusat Statistik Kabupaten Serang). 2016. Kecamatan Pulo Ampel dalam Angka 2016. Serang (ID): BPS Kabupaten Serang.

BPS (Badan Pusat Statistik Kabupaten Serang). 2016. Kabupaten Serang dalam Angka 2016. Serang (ID): BPS Kabupaten Serang.

BPS (Badan Pusat Statistik Kabupaten Serang). 2016. Kecamatan Pontang dalam Angka 2016. Serang (ID): BPS Kabupaten Serang.

BPS (Badan Pusat Statistik Kabupaten Serang). 2016. Kecamatan Tirtayasa dalam Angka 2016. Serang (ID): BPS Kabupaten Serang.

BPS (Badan Pusat Statistik Kabupaten Serang). 2016. 
Kecamatan Tunjung Teja dalam Angka 2016. Serang (ID): BPS Kabupaten Serang.

BSN (Standar Nasional Indonesia). 2011. SNI 7706. 1. Bibit Kerbau. Jakarta (ID): Badan Standardisasi Nasional.

Disperta (Dinas Pertanian Kabupaten Serang). 2016. Kabupaten Serang dalam Angka. Serang (ID): Dinas Pertanian Kabupaten Serang.

Anggraeni, E. Triwulanningsih. 2008. Keragaan bobot badan dan morfometrik tubuh kerbau sumbawa terpilih untuk penggemukan. Seminar dan Lokakarya Nasional Usaha Ternak Kerbau. Brebes (ID): 124-131.

Batoa, H., A. Jahi, \& D. Susanto. 2008. Faktor-faktor yang berhubungan dengan kompetensi petani rumput laut di Kabupaten Konawe Provinsi Sulawesi Tenggara. Jurnal Penyuluhan. 4(1): 30-38.

Maureen C. H., E. Kardiyanto. 2011. Potency of developing buffalo in banten province for supporting beef self sufficiency. Prosiding Seminar dan Lokakarya Nasional Usaha Ternak Kerbau. Lebak Banten (ID):121-126.

Daryanto, A., Y. Hafizrianda. 2010. Model Kuantitatif untuk Perencanaan Pembangunan Ekonomi Daerah. Cetakan I. IPB Pr, Bogor.

Gaspersz. 1991. Teknik Analisis dalam Penelitian Percobaan. Jilid ke-1. Tarsito, Bandung.

Gerli, Hamdan, \& A. H. Daulay. 2012. Karakteristik morfologi ukuran tubuh kerbau murrah dan kerbau rawa di BPTU Siborongborong. J Peternakan Integratif. 1(3): 276-287.

Gunawan, E. Romjali. 2009. Buffalo breeding program. Prosiding Seminar dan Lokakarya Nasional Usaha Ternak Kerbau. Brebes (ID): 3-10

Handiwirawan, E., Suryana, \& C. Talib. 2008. Karakteristik tingkah laku kerbau untuk manajemen produksi yang optimal. Prosiding Lokakarya Nasional Usaha Ternak
Kerbau. Tana Toraja (ID): 97-104.

Komariah, C. Sumantri, H. Nuraini, S. Nurdiati, \& S. Mulatsih. 2015. Potency and development strategies of swamp buffaloes at different topography in Cianjur district West Java Indonesia. IJSBAR. 23(2): 260-270.

Nell, A. J., D. H. L. Rollinson. 2009. The Requirement and Availability of Livesttock Feed in Indonesia. Jakarta (ID): UNDP Project INS/72/2009.

Nurfaridah, A., S. B. Komar, \& S. Nurachma. 2009. Cumulative index of body size and body weight a composite ewe mutton as sheep meet. Bandung (ID): Universitas Padjajaran.

Riwantoro. 2016. Optimalisasi teknologi dan agribisnis peternakan dalam rangka pemenuhan protein hewani asal ternak. Purwokerto (ID): Fakultas Peternakan Universitas Jenderal Soedirman.

Sitorus, A. J., A. Anggraeni. 2009. Karakterisasi morfologi dan estimasi jarak genetik kerbau rawa, sungai (murrah) dan silangannya di Sumatera Utara. Prosiding Lokakarya Nasional Usaha Ternak Kerbau. Tana Toraja: 38-54.

Syamsuddin, H. 2013. Analisis pengaruh faktor kependudukan terhadap pertumbuhan ekonomi Provinsi Jambi. J Paradigma Ekonomika. 1(7): 73-84.

Putra, I. G. 1985. Pendugaan bobot hidup kerbau Lumpur berdasarkan pengukuran morfologi. Tesis. Bogor (ID): Institut Pertanian Bogor.

Utomo, B., S. Prawirodigdo. 2009. Characteristic of buffalo (Bubalus bubalis) rearing in Boyolali District. Prosiding Seminar dan Lokakarya Nasional Usaha Ternak Kerbau. Brebes (ID): 100-108. 